УДК 811/111

ББК 81.2

DOI: https://doi.org/10.17308/lic. 2020.3/2938

\title{
МУЗЫКООБРАЗУЮЩИЕ ОТНОШЕНИЯ В ХУДОЖЕСТВЕННЫХ ТЕКСТАХ Э. БЁРДЖЕССА
}

\author{
Л. В. Коробко \\ Военно-воздуиная академия имени Н. Е. Жуковского и Ю. А. Гагарина

\section{MUSIC-FORMING RELATONS \\ IN THE LITERARY TEXTS OF ANTHONY BURGESS}

\author{
L. V. Korobko \\ N. E. Zhukovsky and Yu. A. Gagarin Air Force Academy
}

\begin{abstract}
Аннотация: настоящая статья посвящена определению пути музыки от композитора к слушателю в художественных текстах Энтони Бёрджесса. Цель настоящей работы заключается в выявлении и описании специфики музыкообразующих отношений в текстах художественных произведений Э. Бёрджесса. В качестве эмпирического материала были использованы тексты художественных произведений Э. Бёрджесса. Предметом исследования являются лексические единиць, номинирующие композитора, исполнителя и слушателя / адресата музыки. В прочессе исследования применялись следуюшие методы: метод контекстуального анализа, метод компонентного анализа с опорой на словарные дефиниции. В ходе работы было установлено, что наряду с субстантивными лексическими единицами, использующимися для репрезентации композитора, исполнителя и слушателя, в текстах анализируемых произведений присутствуют имена собственные, а также дейктические средства (личные местоимения). Характерно, что дейктические средства наблюдаются преимущественно при указании слушателя, что, главным образом, объясняется превалированием местоимения I в качестве адресата музыки в романе «Заводной апельсин», поскольку повествование в нем ведется от первого лица. Исследование показало, что выявленные антропонимы делятся на имена реально существующих музыкантов и фиктивные онимы. С позиции оченочности отмечается положительная коннотация реальных имен собственных и негативная окраска вымышленных имен, прослеживающаяся как в процессе их этимологического анализа, так и на примере лексического окружения. Делается вывод о том, что для художественных текстов Э. Бёрджесса релевантным является коммуникативный музыкальный треугольник «Композитор - Исполнитель - Слушатель». Практическая значимость работь заключается в возможности использовать результаты проведенного исследования в теоретических курсах по лексикологии и стилистике английского языка, межкультурной коммуникации, лингвокультурологии, когнитивной лингвистике.
\end{abstract}

Ключевые слова: художественный текст, Энтони Бёрджесс, музыка, композитор, исполнитель, слушатель, адресат, лексема, антропоним.

Abstract: this article focuses on defining the path of music from a composer to a listener in the literary texts by Anthony Burgess. The purpose of this work is to identify and describe the specifics of musicological relationships in the texts of A. Burgess's literary works. The texts of A. Burgess's literary works were used as the empirical material. The subject of the study is the lexical units nominating a composer, a performing musician and a listener / an addressee. The following methods were used during the study: a contextual analysis method, a component analysis method based on dictionary definitions. In the course of the work, it was found that the texts of the analyzed works contain names as well as deictic means (personal pronouns), along with the substantive lexical units used to represent the composer, the performer and the listener. It is characteristic that the deictic means are observed mainly when the listener is indicated, which is due to the prevalence of the pronoun I as the addressee of music in the novel "A Clockwork Orange", because it is written in the first person. The study showed that the

(С) Коробко Л. В., 2020

Контент доступен под лицензией Creative Commons Attribution 4.0 License.

The content is available under Creative Commons Attribution 4.0 License. 
identified anthroponyms are divided into the names of real musicians and the fictitious onyms. As for the estimability there is the positive connotation of the real names and the negative regard of the fictional names, which is observed both in the process of their etymological analysis and the study of their lexical environment. It is concluded that the communicative musical triangle "A Composer - A Performing Musician - A Listener" is relevant to the literary texts of A. Burgess. The practical significance of the work lies in the possibility of using the results of the conducted study in the theoretical courses of lexicology and stylistics of English, intercultural communication, linguoculturology, cognitive linguistics.

Key words: literary text, Anthony Burgess, music, composer, performing musician, listener, addressee, lexeme, anthroponym.

\section{Введение}

Текст - явление культуры, проявляющееся во всех ее сферах: музыке, литературе, изобразительном искусстве и т. д. [1, с. 54]. В лингвистике текст трактуется чаще всего как «язык в действии» (М. А. К. Хэллидэй). Н. И. Серкова называет текст «речевым знаком» [2, с. 75-82]. По мнению М. И. Откупщиковой, текст представляет собой «сложный языковой знак» [3, с. 27].

Художественный текст является одной из разновидностей текста и представляет интерес для исследователей различных областей, таких как психолингвистика, социолингвистика, когнитивная лингвистика, стилистика и др. Художественный текст моделирует действительность так, как она интерпретируется в сознании писателя. Другими словами, представленная в тексте действительность описывает не окружающий мир, а авторское видение мира: «внутритекстовая действительность есть в буквальном смысле слова совокупность чьих-то ощущений» [4, c. 8]. Художественный текст отражает окружающую реальность, взаимоотношения людей, а также позволяет окунуться в новые миры и перенестись во времени.

Целью настоящей статьи является выявление и описание специфики музыкообразующих отношений в текстах художественных произведений Э. Бёрджесса.

Материалом для исследования послужили такие художественные произведения Э. Бёрджесса, как: 1) «A Clockwork Orange» («Заводной апельсин») (1962 г.), 2) «Earthly Powers» («Силы земные») (1980 г.), 3) «One Hand Clapping» («Однорукий аплодисмент») (1961г.), 4) «Tremor of Intent» («Трепет намерения») (1966 г.). Выбранный материал исследуется методами контекстуального анализа и компонентного анализа с опорой на словарные дефиниции.

\section{Триада}

\section{«Композитор - Исполнитель - Слушатель»}

Музыка представляет собой вид искусства, отражающий авторское (композиторское) мировосприятие и мироощущение. Б. В. Асафьев утверждал: «Мышление и чувствование композитора становятся интонацией», т. е. интонирование трактуется им как отра- жение человеческой мысли в специфических образно-звуковых формах музыкального искусства [5, с. 264]. Асафьев называл музыку «искусством человеческого общения». По мнению ученого, композитор передает адресату определенный «эмоционально-смысловой тонус» [5, с. 225].

Триада «композитор - исполнитель - слушатель» прослеживается в работах известных ученых, музыковедов, социологов. Б. Л. Яворский дал следующую характеристику музыкальных произведений: «процесс от общества, через автора, исполнителя, слушателя снова в общество» $[6$, с. 8]. Ф. И. Шмит определяет музыкальное искусство как особый процесс коммуникации, поскольку в нем присутствует исполнитель, опосредующий общение между композитором и аудиторией, воспринимающей музыку. Шмит придавал исполнителю высокую степень значимости в треугольнике «композитор - исполнитель - слушатель». Ученый утверждал, что «исполнительство дает жизнь, общественное бытие музыкальному произведению, организуя, направляя художественное восприятие публики» [7, с. 11]. Однако не стоит забывать, что восприятие слушателем музыкального произведения должно быть подчинено композиторской интенции.

Известный музыкант Рихтер высказывался относительно исполнительского искусства следующим образом: «Исполнительское искусство? Не очень понимаю, что это такое. Я вообще ничего особенного не делаю; играю только то, что написано в нотах» $[8$, c. 81$]$.

Несмотря на сказанное Рихтером, следует отметить, что каждому музыканту присуща индивидуальность исполнения, поскольку исполнение музыкального произведения являет собой живое, сиюминутное творчество. Слушатель следует за исполнителем, повинуясь ему и его воле. Задача исполнителя состоит в том, чтобы помочь слушателю понять замысел композитора и привести его к постижению музыкального творения. Таким образом, в процессе восприятия музыки слушатель подвергается постоянному воздействию.

Именно через восприятие музыкального произведения закладывается духовная культура человека. Б. М. Теплов писал: «Понять художественное произ- 
ведение - значит, прежде всего, прочувствовать, эмоционально пережить его и уже на этом основании поразмыслить над ним» [9, с. 8].

Е. А. Дубровская отмечает, что на характер музыкального восприятия и ценностные ориентации, помимо наличия способностей или сформированности умений, влияют уровень образования, возраст, социально-демографический слой, формирующие определенные предпочтения в музыке. Ф. Лист указывал: «Восприятие музыки - это познание самого себя» [10, с. 56-57]. Установлено, что любовь к классической музыке зарождается у человека как результат стиля жизни, обусловленного системой ценностей личности.

\section{Путь музыки от композитора к слушателю в художественных текстах Э. Бёрджесса}

Композитор. Создатель музыки - композитор репрезентируется в текстах произведений Э. Бёрджесса посредством указания конкретных имен (Beethoven (Бетховен), Mozart (Моцарт), Bach (Бах) и др.). Кроме того, в анализируемых текстах выделяются примеры с лексемой COMPOSER (композитор). Ср.:

A composer of film music and a denizen of the film capital of the world, he succumbed to the immoral ambience of a culture dedicated to money and pleasure... [11] (Будучи сочинителем кинематографической музыки и жителем мировой кинематографической столицы, он не смог устоять перед окружавшими его искушениями культуры, основанной на культе денег и удовольствий... [12]);

I understood that all that was realised, the difficulty, I mean, of Domenico 's earning his living as a composer of serious music. He says he is still learning his craft [11] (По крайней мере, все понимают как сложно заработать сочинением серьезной музыки. Доменико говорит, что он все ещзе учится этому ремеслу [12]);

Like being able to really appreciate the great composers, Beethoven and Bach and so on [13] (K npuмеру, уметь по-настоящему изенить великих композиторов, Бетховена, Баха и тому подобное [14]).

В фокусных контекстах говорится о «тернистом пути» композиторов, пишущих музыку ради искусства, а не для извлечения прибыли. Композиторы по призванию противопоставляются «коммерческим» композиторам. Так, отмечается, что композитору серьезной музыки (a composer of serious music) сложно заработать на жизнь (the difficulty of earning his living) и добиться признания (being able to really appreciate the great composers), тогда как композиторы, сочиняющие ради выгоды, исповедуют культ денег и удовольствий (dedicated to money and pleasure).
Абсолютной доминантой среди имен композиторов в текстах Э. Бёрджесса выступает имя великого немецкого композитора Ludwig van Beethoven (Людвиг ван Бетховен) [15].

В нижеследующем контексте упоминается целый ряд известных композиторов: Моцарт, Бетховен, Шенберг и Орф. Отмечается использование модели имени [Фамилия музыканта] при упоминании Schoenberg (Шенберг) и употребление модели [Личное имя + Фамилия музыканта] для Carl Orff (Карл Opф). Сp.:

"What shall it be?" asked a veck with otchkies on his nose, and he had in his rookers lovely shiny sleeves full of music. "Mozart? Beethoven? Schoenberg? Carl Orff?” [16] (Ну, кого поставим? - спросил очкастый diadia, тасуя передо мной цчелую стопку пластинок в глянцевых роскошных обертках. - Моцуарта? Бетховена? Шенберга? Карла Орфа? [17]).

You mean an opera about a saint? You don't have operas about saints. Saints are for oratorios. Like Mendelssohn and Handel and all that shit [11] (Tbl имеешь в виду оперу про святого? Про святьх опер не пииут. О святых пишут оратории. Как Мендельсон, Гендель и все прочее дерьмо [12]).

Резко отрицательное отношение к творчеству Генделя (Handel) и Мендельсона (Mendelssohn) выражается посредством экспрессивно окрашенного пейоративно-коннотатированного детерминанта shit (дерьмо), репрезентирующего эстетический тип оценки (по Н. Д. Арутюновой [18]).

В следующем примере, содержащем имя Felix Mendelssohn (Феликс Мендельсон), напротив, наблюдается положительная оценка творчества композитоpa. Cp.:

And then there was old Felix M. with his Midsummer Night's Dream Overture [16] (Потом еще старина Феликс М. со своей увертюрой «Сон в летнюю ночь» [перевод наш]).

Прослеживается деидентификация композитора, употреблена модель [Личное имя + Инициал Фамилии музыканта] - Felix M. При анализе контекста становится очевидным, о каком композиторе идет речь. Это известный немецкий композитор, написавший увертюру «Сон в летнюю ночь», Феликс Мендельсон. Писатель считает, что музыкант является настолько известной личностью, что по названию произведения читатель сможет определить его создателя. Это подтверждает и прилагательное old, которое означает «very well known; someone you have known for a long time» [19] (очень хорошо знакомый; тот, кого ты знаешь уже долгое время). Подобное обращение говорит об отношении к музыканту как к старому приятелю, с которым приятно провести время.

Следующий антропоним, номинирующий фиктивного композитора, Domenico Campanati (Домени- 
ко Кампанати) употребляется согласно моделям [Личное имя + Фамилия музыканта], [Личное имя музыканта], [Фамилия музыканта]. Ср.:

Many a great movie had been ennobled by a Campanati score, and Domenico was, a few years after the war, to receive the supreme accolade of an Oscar for his music to Otto Preminger's The Brothers Karamazov, which brought a famed Dostoevsky novel to the screen [11] (Многие великие фильмы были облагорожены музыкой Кампанати, и через несколько лет после войны Доменико получил высшую награду - Оскар за музыку к фильму Отто Премингера «Братья Карамазовы» по знаменитому роману Достоевского [12]);

Domenico Campanati, the noted light composer, had died earlier this year of thrombosis [11] (Доменико Кампанати, известный композитор, автор легкой музыки умер ранее в этом же году от тромбоза [12]).

Domenico является итальянским вариантом имени Dominic, имеющего латинское происхождение. Дословный перевод имени означает «принадлежащий Господу» [20]. Фамилия Campanati относится к разряду фамилий, связанных с трудовой деятельностью. Подобным именем называли человека, работавшего на церковных колоколах. Буквальное значение фамильного именования Campanati - «маленький церковный колокол» или «звонарь» [20]. Этимологический анализ фокусного антропонима позволяет отнести его к числу имен с религиозной составляющей. Данный антропоним в тексте произведения получает мелиоративную маркированность, что репрезентируется посредством следующих вербальных маркеров: ennobled by (облагорожень), receive the supreme accolade of an Oscar (получил высшию награду Oскар), the noted composer (известный композитор) и др.

Таким образом, в художественных текстах Э. Бёрджесса выделяются как имена всемирно известных композиторов (Handel (Гендель), Mendelssohn (Мендельсон) и др.), так и вымышленные именования (Domenico Campanati (Доменико Кампанати) и др.). Выявленные антропонимы, номинирующие композиторов, используются в языке писателя согласно следующим ономастическим моделям: [Личное имя + Фамилия музыканта], [Личное имя музыканта], [Фамилия музыканта], [Личное имя + Инициал Фамилии музыканта], [Фамилия музыканта + Название музыкального произведения].

Исполнитель. Исполнитель музыки в художественных текстах Э. Бёрджесса эксплицируется посредством наименований музыкантов (pianist (nuaнист), saxophonist (саксофонист), drummer (ударник) и др.) и музыкальных коллективов (orchestra (opкестр), band (джаз-банд), choir / chorus (хор)), a также лексических единиц, номинирующих любителей музыки (veck (человек), drunkie (пьяница)).
Лексема SINGER (певец) относится к наименованиям исполнителей вокальной музыки. Ср.:

There would be some big famous stupid comic chelloveck or black singer, and it was all being bounced off the special telly satellites in outer space, my brothers [16] (Выступал обычно либо какой-нибудь дурацкий знаменитый клоун, либо певец-негр, и всю эту volynku ловили в космосе специиальные телевизионные спутники и отбрасывали обратно на Землю [17]);

...the singer, an epicene willow-wand with a tow lock over his right eye, was singing it... [11] (...певец, извивающийся гермафродит с локоном, упавшим на правый глаз, запел... [12]);

'Is it some sort of a bloody queer ear you'll be wanting yourself?' said a bearded young man, a drunken country singer [21] («Таким же, в который ты сейчас получишь», - буркнул подвыпивиий бородатый парень, местный певеи [22]).

Слово singer характеризуется негативно окрашенной лексикой: эпитетами black, означающим «belonging to the race of people who originally came from Africa and who have dark brown skin» [19] (принадлежащий к расе людей обычно родом из Африки или имеющим более темный цвет кожи), и drunken (подвыпивший), а также определением an epicene willow-wand (извивающийся гермафродит). Актуализируется признак неуважительного отношения к исполнителям.

Лексическая единица ORCHESTRA (оркестр) является символом классической музыки. Ср.:

Large orchestra with saxophones [11] (Большой оркестр с саксофонами [12]).

Оркестр описывается прилагательным large (большой, грандиозный). Подчеркивается масштабность оркестрового исполнения музыки.

В контекстах с лексемами, номинирующими исполнителей, присутствует информация о жанре музыки (популярная), целевой аудитории, манере исполнения музыкальных произведений и их актуальности, выражается личностное отношение к музыке (таблица).

Обратимся к примерам:

It also played, in honour of the new pact, the "Song of the Volga Boatmen" The laughing drinkers, pretty women and solid burgesses and slim men in uniform, relaxed, civilised, some of them joining facetiously in the yo-oh heave-ho... [11] (Ещее он играл "Дубинушку» в честь недавно заключенного пакта. Смеюшиеся пьяницы, миловидные женшины и дородные бюргерии, стройные мужчины в униформе, все раскрепощеннные, циивилизованные, некоторые даже подпевали «Эй, ухнем»... [12]).

В приведенном контексте наблюдается перечисление различных категорий исполнителей: DRINKERS (пьяницыь), WOMEN (женщзины), BURGESSES (бюр- 
Т а б л и ц а

Семантические корреляции между вербально маркированными «Исполнителем музыки», «Предметом музыки» и «Оиеночныли детерминантами музыки» в произведениях Э. Бёрджесса

\begin{tabular}{|c|c|c|}
\hline Исполнитель музыки & $\begin{array}{c}\text { Предмет } \\
\text { музыки }\end{array}$ & $\begin{array}{c}\text { Оценочные } \\
\text { детерминанты } \\
\text { музыки } \\
\end{array}$ \\
\hline $\begin{array}{c}\text { pyahnitsa, drunkie } \\
\text { (пьяница) }\end{array}$ & \multirow[b]{2}{*}{ songs (песни) } & filthy (поганый) \\
\hline $\begin{array}{c}\text { old Dim (паршивец } \\
\text { Тем) }\end{array}$ & & $\begin{array}{c}\text { like a lomtick of } \\
\text { redhot meat (будто } \\
\text { ломтик горячей } \\
\text { сосиски) }\end{array}$ \\
\hline $\begin{array}{l}\text { white-coated veck } \\
\text { (медбрат) }\end{array}$ & \multirow{2}{*}{$\begin{array}{c}\text { pop-song } \\
\text { (популярная } \\
\text { песенка) }\end{array}$} & $\begin{array}{l}\text { vonny cally } \\
\text { (вонючий) }\end{array}$ \\
\hline $\begin{array}{c}\text { teenage malchicks, } \\
\text { ptitsas (тинэйджеры, } \\
\text { подростки) } \\
\end{array}$ & & $\begin{array}{c}\text { new horrible } \\
\text { (новые жуткие) }\end{array}$ \\
\hline veck (человек, дядя) & $\begin{array}{l}\text { sleeves full of } \\
\text { music (стопка } \\
\text { пластинок) }\end{array}$ & $\begin{array}{c}\text { lovely } \\
\text { (роскошный) }\end{array}$ \\
\hline $\begin{array}{c}\text { laughing drink- } \\
\text { ers (смеющиеся } \\
\text { пьяницы), pretty } \\
\text { women (миловидные } \\
\text { женщины), solid } \\
\text { burgesses (дородные } \\
\text { бюргерши), slim men } \\
\text { in uniform (стройные } \\
\text { мужчины } \\
\text { в униформе) }\end{array}$ & $\begin{array}{c}\text { "Song of the } \\
\text { Volga Boatmen" } \\
\text { («Дубинушка») }\end{array}$ & - \\
\hline
\end{tabular}

герши), MEN IN UNIFORM (мужчины в униформе). Отмечается объединение различных слоев общества. .... we viddied by the main bar's long lighted window, a burbling old pyahnitsa or drunkie, howling away at the filthy songs of his fathers... [16] (...мй сквозь ее широкую витрину zasekli cmарого hronika, в смысле пьянииу, распевавшего поганые песни своих поганых предков [17]).

В данном контексте в фокусе внимания находятся исполнители-пьяницы (pyahnitsa or drunkie), которые распевают старые песни (songs). Причастие howling (от глагола howl - издавать громкий протяжный звук (о животных)) отражает манеру пения. Песням дается определение, выраженное пейоративно-коннотатированным прилагательным filthy, peпрезентирующим эстетический тип оценки (по Н. Д. Арутюновой [18]). На старомодность песен указывает упоминание о предках, исполняющего их человека of his fathers. Следует отметить неуважительное отношение к старшему поколению, проявляющемуся в агрессии и отрицании любого элемента жизнедеятельности, коррелирующего с их эпохой.

What happened now was that one white-coated veck strapped my gulliver to a like head-rest, singing to himself all the time some vonny cally pop-song [16] (Потом пошли vestshi и вовсе необычайные; один из теdbrattjev пристегнул мне голову ремнем к подголовнику, напевая при этом себе под нос какую-то популярную вонючую песенку [17]).

Исполнителем песни является медицинский брат - white-coated veck. Песня жанра популярной музыки получает нелестное определение, выраженное отрицательно окрашенными адъективными маркерами vonny, cally, которые являются примерами молодежного жаргона: vonny образовано от существительного von - «smell» [16], заимствованного из русского языка и означающего «вонь»; cally - от существительного cal означает «feces» [Ibid.] (испражнения, фекалии).

Поп-музыка, вне зависимости от времени ее создания, по мнению Э. Бёрджесса, может интересовать только людей с невысоким интеллектом - людей низших слоев общества (пьяниц) и подростков. Поскольку музыка этого жанра не требует больших эмоциональных и умственных затрат, она не может считаться качественной и заслуживающей внимания духовно развитого человека.

Отдельного внимания в произведениях Э. Бёрджесса заслуживают имена собственные, номинирующие музыкантов (Berti Laski (Берти Ласки), Ike Yard (Aйк Яpд) и др.) и музыкальные группы (The Heaven Seventeen («Хевен Севентин») и др.) [23]. Приведем пример.

Имя вымышленного пианиста Albert Poupon (Альберт Пупон) употребляется в соответствии с ономастическими моделями [Личное имя + Фамилия музыканта] и [Фамилия музыканта]. Ср.:

Domenico $<\ldots>$ being commissioned to compose for the pianist Albert Poupon [11] (Доменико < ..> получил заказ от пианиста Альбера Пупона [12]);

... and then Poupon waddled on to applause extravagantly acknowledged. He was like a prosperous provincial grocer whose pastime was dancing, bald with an old-time walrus moustache, a carnation nodding in his buttonhole. He spent an excruciating two minutes adjusting his piano seat, cracked all his fingers in a manner that suggested he was counting the tempo for Pierné, then smashed out the opening solo two measures [11] (...затем под бурные аплодисменты вышел Пупон. Он был похож на зажиточного провинциального бакалейщика, любителя танцев: лысый, со старомодными моржсовыми усами, с гвоздикой в петлице. В течение долгих двух минут он поправлял рояльный табурет, трещал пальцами, как будто задавая Пьерне нужный темп, затем выдал первые аккорды начального соло [12]);

Acclamation, Poupon pointing to Domenico in the audience [11] (Восторги, аплодисменть, Пупон благодарным жестом указывает на Доменико [12]). 
Фонетический строй фамилии Poupon позволяет говорить о его принадлежности к французскому этносу; poupon в переводе с французского означает «младенец, малютка, пупсик». Имя Albert германского происхождения, является краткой формой имени Адальберт (нем. Adalbert), которое образовалось сложением основ [adal] («благородный») и [berht] («яркий», «блистательный») и в переводе означает «благородный блеск» [20].

Анализируемый антропоним относится к разряду «говорящих» имен, что подтверждается литературной характеристикой и описанием персонажа. Так, подтверждением звучности имени Albert являются благородные жесты музыканта (graciously pointing), восторженность зрителей (to applause extravagantly acknowledged (под бурные аплодисменmы ), acclamation (восторги, аплодисменты)). Тогда как внешний вид (like a prosperous provincial grocer whose pastime was dancing (похож на зажиточного провинцииального бакалейщика, любителя танцеев), bald (льссый), with an old-time walrus moustache (co старомодными моржовыми усами), а сагnation nodding in his buttonhole (с гвоздикой в петлиизе)) и манеры (spent an excruciating two minutes adjusting his piano seat (в течение долгих двух минут он поправлял рояльный табурет), cracked all his fingers (трещзал пальцуами), waddle (ходить вразвалку)) исполнителя отражают комичность его фигуры, что еще более подчеркивается фамилией музыканта Роироп (Пупон).

В результате анализа контекстов было установлено, что к числу исполнителей музыки в текстах произведений Бёрджесса относятся профессиональные музыканты (singer (певеu), pianist (пианист), Albert Poupon (Альберт Пупон) и др.) и музыкальные коллективы (orchestra (оркестр), The Heaven Seventeen («Хевен Севентин») и др.), а также любители музыки самых разных слоев общества, социального статуса и возраста (drunkie (пьяниия), white-coated veck (медбpam), teenage malchicks, ptitsas (тинэйджеры, подростки), slim теп in uniform (стройные мужчины в униформе) и др.).

Адресат / слушатель. Музыка существует только тогда, когда ее используют по назначению - слушают. Адресат музыки зачастую выражается дейктическими средствами. Так, в качестве слушателя в романе «Заводной апельсин» Э. Бёрджесса указывается преимущественно главный герой. Роман построен на отношениях героя с музыкой, через музыку повествователь связан с композиторами. Таким образом, роман является музыкоцентричным.

Поскольку в романе «Заводной апельсин» повествование ведется от первого лица, адресат музыки репрезентируется в тексте посредством местоимения $I$ (я). Ср.:
As I slooshied, my glazzies tight shut to shut in the bliss $\langle\ldots\rangle$ and indeed when the music, which was one movement only, rose to the top of its big highest tower, then, lying there on my bed with glazzies tight shut and rookers behind my gulliver, I broke and spattered and cried aaaaaaah with the bliss of it. And so the lovely MUSIC glided to its glowing close [16] (Слушая, я держал glazzја плотно закрытыми, чтобы не sрияпитt наслаждение $<\ldots>>$, конечно же, когда музыка в первой части концерта взмыла к вершине высочайшей башни, я, как был, лежа на спине с закинутыли за голову руками и плотно прикрытыли glazzјаті, не выдержал и с криком «а-а-a-ах》 выбрызнул из себя наслаждение. Потом прекрасная музыка, подступая все ближе, пошла плавно снижаться [17]).

Следуя за мелодией, слушатель (главный герой романа) старается не спугнуть возникшее чувственное удовольствие - my glazzies tight shut to shut in the bliss, и когда композиция достигает своего апогея, он также испытывает наслаждение - I broke and spattered and cried aaaaaaah with the bliss of it, после которого следует эйфория, а мелодия подходит к завершению - glided to its glowing close. Музыка получает определение lovely (прекрасный), что говорит о восхищении слушателя.

Субъект действия music употребляется при предикатах, выраженных глаголами rise и glide в форме прошедшего времени (rose, glided), репрезентирующих динамику развития музыкального действия. Музыка уподобляется половому акту, нарастающее напряжение - rose to the top of its big highest tower (взмыла к вериине высочайшей башни), сменяется чувством глубокого удовлетворения - glided to its glowing close (пошла плавно снижаться). Таким образом, музыка оказывает мощное эмоциональное воздействие, которое трансформируется в физическое удовольствие.

Perhaps, knowing the joy I had in my night MUSIC, they had already taken them. As I slooshied, my glazzies tight shut... [16] (А может, зная о моем пристрастии к музыке по ночам, они его уже приняли. Слушая, я держал glazzjа плотно закрытылми... [17]);

Everybody began to leave nice and quiet while I laid there with my glazzies closed, slooshying the lovely music [16] (Народ на изыпочках, молча стал расходиться, а я лежал с закрытыми глазами и слушал восхитительную музыку [17]).

Синонимичные фразы my glazzies tight shut, my glazzies closed (плотно закрытые глаза) символизируют блаженство, желание слушателя полностью раствориться в музыке, забыв о настоящем, перенестись в сладостный (lovely) мир звуков и ощущений. Актуализируется признак абстрагирования, ухода от реальности, погружения в свой внутренний мир. 
I wanted music very bad this evening, that singing devotchka in the Korova having perhaps started me off. I wanted like a big feast of it before getting my passport stamped, my brothers, at sleep's frontier and the stripy shest lifted to let me through [16] (В тот вечер я страшно соскучился по настоящей музыке - может быть, из-за той kisy в баре «Korova». Перед тем, как на въезде в зону сна мне проштемпелюют паспорт и приподнимут полосатый shest, мне хотелось еще успеть как следует ею насладиться [17]).

В фокусе внимания находится физическое и эмоциональное восприятие музыки, влияющее на морально-психологическое состояние слушателя, музыка представлена как объект, вызывающий определенное состояние.

Главный герой жаждет насладиться музыкой (wanted music), сила его желания не оставляет его ни на минуту, о чем свидетельствует наречие $b a d$, усиленное наречием very (очень). Bad является разговорным вариантом badly в значении «to a great or serious degree» [19] (в высокой или серьезной степени). Прослушивание музыки сравнивается с большим праздником (like a big feast of it). Таким образом, музыка представляется как грандиозное событие, дарящее восторг, радость, незабываемые, яркие эмоции.

Слушатель в произведениях Э. Бёрджесса также эксплицируется следующими местоимениями.

THEY (они). Сp.:

...the one with the green wig, kept pushing her belly out and pulling it in in time to what they called the music [16] (Одна из mpex kisok у стойки, та, что была в зеленом парике, то выпячивала живот, то снова его втягивала в такт тому, что у них называлось музыкой [17]).

В представленном контексте описывается вечер в баре с некоторым подобием танцев (kept pushing her belly out and pulling it in). Посетители (they) танцуют под звуки, которые с трудом можно назвать музыкой, что репрезентируется на примере фразы - what they called the тияіс (тому, что у них называлось музыкой). Глагол call означает «to have a particular name or title, or use a particular name or title for someone or something») [19] (иметь особое название или использовать особое название для кого-либо или чего-либо). Таким образом, звучащую композицию с трудом можно отнести к настоящей музыке. Актуализируется презрительное отношение к людям, не разбирающимся в музыке, а также к музыке низкого сорта.

$Y O U(\mathrm{mbl})$ :

If you have not heard the music, then how can you know that it is not good? [11] (И если вы ее [музыку] не сльшали, то откуда вам известно, что она нехорома? [12]);

"Music," said Dr. Brodsky, like musing. "So you're keen on mиsic [16] (Музыку, - задумчиво произнес доктор Бродский. - Так ты, стало быть, музыку любишь [17]).

Посредством адъективного маркера keen во фразe be keen on - «to like someone or something» [19] (испытывать симпатию к кому-либо или чему-либо) выражается любовь слушателя к музыке.

В нижеследующих контекстах музыка представлена как объект каузирующего состояния при следующих субъектах-адресатах музыки.

LIEBENEINER (Либенайнер):

And yet this man Liebeneiner, who had after all taught the English language and analysed poems by Shelley and speeches by Shakespeare, who loved music... [11] (И тем не менее этот человек Либенайнер, который, между прочим, когда-то преподавал английский язык, разбирал стихи Шелли и монологи Шекспира, любил музыку... [12]).

ITALIANS (итальяниы):

Italians laughing at music? Goodness, I thought Italians were the first people in the world for loving music [11] (Итальянцы, смеюшиеся над музыкой? Боже мой, я всегда считала, что итальянцы - самый музыкальный народ в мире [12]).

В фокусных контекстах актуализируется признак увлеченности, привязанности, получения эстетического удовольствия слушателями от музыки. Объект каузирующего состояния тиsic употребляется при предикатах, отражающих каузирующее состояние любовь слушателей к музыке, репрезентированное глаголом love.

Целевой аудиторией популярной музыки выступают подростки, тинэйджеры: MALCHICKS (мальчики), PTITSAS (киски = девочки):

...only a scream and a creech of nadsat (teenage, that is) malchicks and ptitsas slooshying some new horrible popsongs... [16] (...одни визги и вопли надсатных (тинэйджеров, стало быть) мальчиков и кисок, которые слушали свой излюбленные популярные песен$\kappa и . . .[$ перевод нам]).

Песни, написанные в жанре поп-музыки, характеризуются посредством эпитета horrible - «very unpleasant» [19] (очень неприятный). Актуализируется неприятие по отношению к музыкальным произведениям.

Следующей лексемой, номинирующей адресата музыки, является AUDIENCE (публика). Ср.:

Afair audience, mostly there to hear Albert Poupon ... [11] (Изысканная публика, пришедшая слушать в основном Альбера Пупона ... [12]).

ЛЕ audience получает положительную маркированность, реализующуюся на примере эпитета fair (изысканный).

Таким образом, слушатель в текстах Бёрджесса репрезентируется, главным образом, посредством личных местоимений $(I(\Omega)$, they (они), уои $(m b l))$, 
кроме того, в качестве адресатов музыки представлены имена собственные (Liebeneiner (Либенайнер), Hortense (Ортенс)) и субстантивные лексемы (audience (публика), malchick (мальчик) и др.).

Проведенный анализ позволил установить, что для художественных текстов Э. Бёрджесса релевантной является триада «Композитор - Исполнитель Слушатель». Участниками коммуникативного процесса со слушателем всегда являются двое: композитор и исполнитель.

Ономастическое пространство художественных произведений Энтони Бёрджесса представлено реальными и фиктивными именами музыкантов, как композиторов, так и исполнителей.

Появление фиктивных имен музыкантов и музыкальных названий в художественных текстах писателя отражает свободу выражения индивидуально-авторского отношения к музыке и ее создателям.

В произведениях Э. Бёрджесса обращает на себя внимание противопоставление двух музыкальных жанров: классической и популярной музыки. Поп-музыка рассматривается как неполноценная, подходящая для людей со скудным интеллектуальным и духовным развитием. Негативное, пренебрежительное отношение к популярной музыке репрезентируется посредством отрицательно окрашенных оценочных лексем: horrible (жуткий), filthy (поганый) и др. Классическая музыка, в свою очередь, характеризуется как источник мощного эмоционального воздействия и духовного роста. Актуализируется признак уважительного, порой благоговейного отношения к музыкантам и их произведениям, что продемонстрировано на примере оценочных маркеров с положительной коннотацией (lovely (чудесный), great (великий) и др.).

\section{ЛИТЕРАТУРА}

1. Рубциова С. П. Художественный текст как предмет понимания в лингвистике и философии // Вестник Воронеж. гос. ун-та. Сер.: Филология. 2017. № 4. С. 54-68.

2. Серкова Н. И. Предпосылки членения текста на сферфразовом уровне // Вопросы языкознания. 1978. № 3. C. 75-82.

3. Откупщикова М. И. Синтаксис связного текста. Л. : Изд-во ЛГУ, 1982. 103 с.

4. Борухов Б. Л. Онтология художественного текста // Художественный текст : онтология и интерпретация. Саратов : СГПИ, 1992. С. 4-16.

5. Асафьев Б. В. Музыкальная форма как процесс. Л. : Музыка, 1971. 376 с.

6. Яворский Б. Л. Избранные труды : в 2 т. Т. 1. Статьи, воспоминания, переписка. М. : Советский композитор, 1972.

7. Шмит Ф. И. Искусство. Основные проблемы теории и истории. Л. : Музыкальный сектор, 1925. 184 с.
8. Цыпин Г. М. Психология музыкальной деятельности : проблемы, суждения, мнения. М. : Владос, 1994. $373 \mathrm{c}$.

9. Теплов Б. М. Психологические вопросы художественного воспитания // Известия АПН. 1947. № 11. C. 7-26.

10. Дубровская E. A. Музыкальное развитие детей в триаде «композитор исполнитель слушатель» // Вестник МГПУ. Серия «Педагогика и психология». М., 2008. № 4 (29). C. 54-60. $656 \mathrm{p}$

11. Burgess A. Earthly Powers. Random House, 2012.

12. Бёрджесс Э. Силы земные. URL: https://www. proza.ru/2013/08/05/97

13. Burgess $A$. One hand clapping. Bloomsbury Publishing, 2015. 80 p.

14. Бёрджесс Э. Однорукий аплодисмент / пер. с англ. Е. В. Нетесовой. М. : Центрполиграф, 2002. 223 с.

15. Коробко Л. В. Имя Людвига ван Бетховена как прецедентная единица в романе Э. Бёрджесса «Заводной апельсин» // Вестник Кемер. гос. ун-та. 2017. № 1. C. $169-177$.

16. Burgess A. A Clockwork Orange. KAPO, 2015. 288 p.

17. Бёрджесс Э. Заводной апельсин / пер. с англ. В. Бошняка. М. : АСТ, 2010. 226 с.

18. Арутюнова Н. Д. Типы языковых значений : Оценка. Событие. Факт. М. : Наука, 1988. 341 с.

19. The Longman Dictionary of Contemporary English Online. URL: http://www.ldoceonline.com.

20. Behind the name : the etymology and history of first names. URL: http:/www.behindthename.com

21. Burgess A. Tremor of Intent. W. W. Norton \& Company, 2013. 272 p.

22. Бёрджесс Э. Трепет намерения / пер. с англ. А. Д. Смолянского. М. : АСТ, 2010. 320 с.

23. Коробко Л. В. Этимологические и транскультурные составляющие фиктивных имен музыкантов и номинаций музыкальных групп (на материале романа Энтони Бёрджесса «Заводной апельсин») // Научный вестник Воронеж. гос. архит.-строит. ун-та. Сер.: Современные лингвистические и методико-дидактические исследования. 2016. № 2 (30). С. 135-150.

\section{REFERENCES}

1. Rubcova S. P. Hudozhestvennyj tekst kak predmet ponimaniya $\mathrm{v}$ lingvistike i filosofii [Literary Text as a Subject of Understanding in Linguistics and Philosophy]. In Proceedings of Voronezh State University. Series: Phylology. 2017. No. 4. Pp. 54-68.

2. Serkova N. I. Predposylki chleneniya teksta na sferfrazovom urovne [Prerequisites for Text Membership at Spherical Level]. In Voprosy yazykoznaniya. 1978. No. 3. Pp. 75-82.

3. Otkupshchikova M. I. Sintaksis svyaznogo teksta [Syntax of the connected text]. L. : Izd-vo LGU, 1982. 10 p.

4. Boruhov B. L. Ontologiya hudozhestvennogo teksta [Ontology of the literary text]. In Hudozhestvennyj tekst: 
ontologiya i interpretaciya. Saratov : SGPI, 1992. Pp. 4-16.

5. Asaf"ev B. V. Muzykal'naya forma kak process [Musical Form as a Process]. L.: Muzyka, 1971. 376 p.

6. Yavorskij B. L. Izbrannye trudy : v 2-h tt. [Selected works: in 2 vol.]. In T. 1. Stat'i, vospominaniya, perepiska. Moscow: Sovetskij kompozitor, 1972.

7. Shmit F. I. Iskusstvo. Osnovnye problemy teorii $\mathrm{i}$ istorii [Art. Main problems of theory and history]. L. : Muzykal'nyj sektor, 1925. 184 p.

8. Cypin G. M. Psihologiya muzykal'noj deyatel'nosti: problemy, suzhdeniya, mneniya [Psychology of Musical Activity: Problems, Judgements, Opinion]. Moscow: Vlados, 1994. 373 p.

9. Teplov B. M. Psihologicheskie voprosy hudozhestvennogo vospitaniya [Psychological issues of art education] In Izvestiya APN. 1947. No. 11. Pp. 7-26.

10. Dubrovskaya E. A. Muzykal'noe razvitie detej v triade «kompozitor ispolnitel' slushatel'»[Musical development of children in the triad "a composer a performer a listener"]. In Vestnik MGPU. Seriya «Pedagogika $i$ psihologiya». Moscow, 2008. No. 4 (29). Pp. 54-60.

11. Burgess A. Earthly Powers. Random House, 2012. $656 \mathrm{p}$.

12. Burgess A. Sily zemnye [Earthly Powers]. Available at: https://www.proza.ru/2013/08/05/97

13. Burgess A. One hand clapping. Bloomsbury Publishing, 2015. 80 p.

14. Byordzhess E. Odnorukij aplodisment [One hand clapping]; per. s angl. E. V. Netesovoj. Moscow: Centrpoligraf, 2002. $223 \mathrm{p}$.

Военно-воздушная академия имени Н. Е. Жуковского и Ю. А. Гагарина

Коробко Л. В., преподаватель кафедры иностранных языков

E-mail:l.v.ledeneva@mail.ru

Поступила в редакциюю 18 февраля 2020 г.

Принята к публикаџии 15 июня 2020 г.

\section{Для цитирования:}

Коробко Л. В. Музыкообразующие отношения в художественных текстах Э. Бёрджесса // Вестник Воронежского государственного университета. Серия: Лингвистика и межкультурная коммуникация. 2020. № 3. C. 94-102. DOI: https://doi.org/10.17308/lic. 2020.3/2938
15. Korobko L. V. Imya Lyudviga van Bethovena kak precedentnaya edinica $v$ romane E. Byordzhessa «Zavodnoj apel'sin» [Ludwig van Beethoven's name as a case unit in A. Burgess's novel «A Clockwork Orange«]. In Vestnik Kemerovskogo gosudarstvennogo universiteta. 2017. No. 1. Pp. 169-177.

16. Burgess A. A. Clockwork Orange. KARO, 2015. $288 \mathrm{p}$.

17. Burgess A. Zavodnoj apel'sin [A Clockwork Orange]; per. s angl. V. Boshnyaka. AST, 2010. 226 s.

18. Arutyunova N. D. Tipy yazykovyh znachenij: Ocenka. Sobytie. Fakt [Types of language values: Assessment. Event. Fact]. Moscow : Nauka, 1988. 341 p.

19. The Longman Dictionary of Contemporary English Online. Available at: http://www.ldoceonline.com

20. Behind the name: the etymology and history of first names. Available at: http://www.behindthename.com

21. Burgess A. Tremor of Intent. W. W. Norton \& Company, 2013. 272 p.

22. Burgess A. Trepet namereniya [Tremor of Intent]; per. s angl. A. D. Smolyanskij. AST, 2010. 320 p.

23. Korobko L. V. Etimologicheskie i transkul'turnye sostavlyayushchie fiktivnyh imyon muzykantov i nominacij muzykal'nyh grupp (na materiale romana Entoni Byordzhessa «Zavodnoj apel'sin») [Etymological and transcultural components of fictitious names of musicians and nominations of bands (based on the novel of Anthony Burgess «A Clockwork Orange»)]. In Nauchnyj vestnik Voronezhskogo gosudarstvennogo arhitekturno-stroitel'nogo universiteta. Ser. Sovremennye lingvisticheskie i metodiko-didakticheskie issledovaniya. 2016. No. 2 (30). Pp. 135-150.

N. E. Zhukovsky and Yu. A. Gagarin Air Force Academy Korobko L. V., Lecturer of the Foreign Languages Department

E-mail: l.v.ledeneva@mail.ru

Received: 18 February 2020

Accepted: 15 June 2020

\section{For citation:}

Korobko L. V. Music-forming relatons in the literary texts of Anthony Burgess. Proceedings of Voronezh State University. Series: Linguistics and Intercultural Communication. 2020. No. 3. Pp. 94-102. DOI: https://doi.org/ 10.17308/lic. 2020.3/2938 